\title{
ANALISIS FAKTOR DETERMINAN KEJADIAN KEK PADA IBU HAMIL DI RSIA CITRA KELUARGA KEDIRI TAHUN 2015
}

\author{
Ribut Eko Wijanti, Indah Rahmaningtyas, Suwoyo \\ Prodi Kebidanan Kediri, Jl. KH. Wachid Hasyim 64B Kediri \\ email : indah.rahmaningtyas@yahoo.com
}

\begin{abstract}
Undernutrition is still a major health problem in Indonesia, An example of undernutrition is chronic deficiency at pregnant woman. This incident brings an impact to the health of next generation, The research objective was determining factors with affect chronic energy deficiency at pregnant women in RSIA Citra Keluarga of Kediri. Design used in study is analytic method. The sampling technique used is accidental sampling. The population in this study were all pregnant womwn who reside in Antenatal Care to RSIA Citra Keluarga Kediri. The sample size used was 33 respondents. The analysis results of Spearrman test were with alpha value $=5 \%$ were 1) Education $p$-value $=0,009.2)$ Age $p$ value $=0,027,3)$ Parity $p$-value $=0,999.4)$ Range pregnant $p$-value $=0,999$. Based on this study multivariate regresi model, the factors that affect chronic energy deficiency at pregnant women are $O R$ value of the education variable is 12,000 and OR value of the age variable is 5,595. Conclution from the study sugegested which means 12 times the maternal education affect chronic energy deficiency, and means 5,595 times the maternal age affect chronic energy deficiency. So we must do the prevention by conseling and chech body mass index before pregnant.
\end{abstract}

\section{Keywords : Incident of Cronic Deficiency in Pregnant Woman, The Dominant Affecting}

\section{PENDAHULUAN}

Tiga faktor utama indeks kualitas hidup yaitu pendidikan, kesehatan, dan ekonomi. Ketiga faktor tersebut erat kaitannya dengan status gizi masyarakat yang dapat digambarkan terutama pada status gizi anak balita dan wanita hamil (Harahap, 2002). Tujuan penatalaksanaan gizi pada wanita hamil adalah untuk mencapai status gizi ibu yang optimal sehingga ibu menjalani kehamilan yang aman, melahirkan bayi dengan potensi fisik dan mental yang baik (Proverawati, 2009).

Kementerian Koordinator Kesejahteraan Rakyat pada tahun 2010 mencatat angka kematian ibu hamil menembus angka 228 dari 100.000 kelahiran hidup. Ada 13 provinsi yang memiliki angka kematian ibu amat tinggi, diantaranya Papua dan Nusa Tenggara Timur (Irpisar, 2012). Jumlah Kematian Maternal di Provinsi JawaTimur berdasarkan Laporan Kematian Ibu Kabupaten/Kota pada tahun 2010 tercatat sebanyak 598 kasus kematian. Bila dilihat dari masa kematian ibu maka dapat dirinci 152 kematian masa hamil, 163 waktu bersalin, dan 283 pada masa nifas. Berdasarkan data dari dinas Kota Kediri pada tahun 2013 jumlah kematian ibu sebanyak 37 orang, beberapa masalah kesehatan pada ibu hamil ini, meliputi anemia setelah melahirkan, pertambahan berat badan rendah, dan kekurangan energi kronis (KEK) (Irpisar, 2012).

Menurut Depkes RI tahun 2009, prevalensi ibu hamil KEK yaitu 24,6\% dan Provinsi JawaTimur sebanyak 27,5\% (Sandjaja, 2009). Berdasarkan data dari RSIA Citra Keluarga kejadian KEK tahun 2013 mencapai 59 orang dari 683 ibu hamil. Kejadian KEK Januari-Desember 2014 sebanyak 72 dari 619 ibu hamil. Data tersebut menunjukkan adanya kecenderungan peningkatan kejadian 
KEK pada ibu hamil di RSIA Citra Keluarga Kediri sejak periode JanuariDesember 2013 dengan Januari-Desember 2014.

Penyebab langsung kematian ibu antara lain dikarenakan oleh perdarahan, eklampsia, partus lama, komplikasi aborsi, dan infeksi. Beberapa faktor tersebut erat kaitannya dengan status gizi masyarakat yang dapat digambarkan terutama pada status gizi anak balita dan wanita hamil (Harahap, 2007).

Kehamilan merupakan proses pembentukan manusia baru (reproduksi), yang perlu disiapkan baik fisik maupun mental sehingga proses tumbuhkembang bayi tersebut, dapat berlangsung secara normal dan sehat guna terciptanya sumberdaya manusia berkualitas (Achin. A., 2003). Ibu hamil harus cermat dalam memilih makanan yang akan dikonsumsi, karena selain untuk memenuhi nutrisi bagi tubuhnya, juga untuk mencukupi kebutuhan gizi janin dalam kandungan (Ari, F., 2010). Asupan gizi pada ibu hamil sangat menentukan kesehatannya maupun janin yang dikandungannya. Janin sangat bergantung pada ibunya untuk pernafasan, pertumbuhan, dan untuk melindunginya dari penyakit. Makanan yang dikonsumsi ibu hamil dipergunakan untuk pertumbuhan janin sebesar $40 \%$, sedangkan yang $60 \%$ untuk memenuhi kebutuhan ibu. Makanan yang dikonsumsi ibu hamil berguna juga, dalam rangka memudahkan proses kelahiran dan untuk produksi ASI bagi bayi yang akan dilahirkan (Paath, 2004).

Menurut Departemen Kesehatan, batas ibu hamil yang disebut sebagai risiko KEK jika ukuran LILA kurang dari 23,5 cm. Perlu diperhatikan juga cara pengukuran LILA yang benar, salah satunya dengan cara pembacaan skala yang benar (Arisman, 2007). Selain itu deteksi KEK sebelum hamil dapat diukur melalui Indeks Massa Tubuh (IMT), bila seorang calon ibu memiliki IMT < 18,0 maka perlu perhatian untuk segera menaikkan berat badannya (Sandjaja,
2009). Beberapa faktor yang mempengaruhi KEK pada ibu hamil adalah factor social ekonomi, pendidikan, pekerjaan, pendapatan, factor jarak kelahiran, faktor paritas (Suparyanto, 2011). Selain itu faktor yang mempengaruhi gizi ibu hamil adalah umur, aktivitas, suhu lingkungan, status kesehatan, juga kebiasaan dan pandangan wanita terhadap makanan (Paath, 2005).

Ibu hamil yang menderita KEK mempunyai risiko kematian mendadak pada masa perinatal, kematian saat persalinan, perdarahan, pasca persalinan yang sulit karena lemah dan mudah mengalami gangguan kesehatan (Waryono, 2010). KEK juga digunakan untuk prediktor terhadap risiko melahirkan bayi berat lahir rendah (BBLR). Setiap bayi yang BBLR mempunyai risiko kematian, gizi kurang, gangguan pertumbuhan, dan gangguan perkembangan anak (Sandjaja, 2009).

Penanggulangan masalah gizi kurang, perlu dilakukan secara terpadu antar departemen dan kelompok profesi, melalui upaya-upaya peningkatan pengadaan pangan, penganekaragaman produksi dan konsumsi pangan, peningkatan status social ekonomi, pendidikan keluarga dan kesehatan masyarakat, serta peningkatan teknologi hasil pertanian dan teknologi pangan. Semua upaya ini bertujuan memperoleh perbaikan pola konsumsi pangan masyarakat yang beranekaragam dan seimbang dalam mutu gizi. Kondisi ini akan menyebabkan peningkatan angka kematian ibu (AKI) dan angka kematian bayi (AKB) (Sunita, 2005).

Berdasarkan fenomena tentang kecenderungan peningkatan kejadian KEK pada ibu hamil di RSIA Citra Keluarga Kediri yang bila tidak ditangani dapat menyebabkan tingginya angka kematian maternal, menurut peneliti hal ini merupakan sesuatu yang urgent. Berdasarkan pertimbangan waktu, tenaga, biaya, kesesuaian kompetensi dan ciri responden untuk pengukuran, maka 
penelitian ini dimungkinkan untuk dilaksanakan. Jika dilakukan penelitian juga dapat membawa manfaat baik bagi responden maupun institusi tempat penelitian, maka peneliti tertarik untuk mengungkap tentang "Analisis Faktor Determinan Kejadian KEK pada Ibu Hamil di RSIA Citra Keluarga Kediri Tahun 2015".

\section{METODE PENELITIAN}

Rancangan yang digunakan dalam penelitian ini adalah kuantitatif, analitik korelasional. Berdasarkan waktu pengumpulan data termasuk penelitian cross sectional, yaitu penelitian yang mencari faktor yang mempengaruhi terjadinya KEK dan dilakukan pada satu saat (sekali waktu).

Populasi dalam penelitian ini adalah seluruh ibu hamil yang mengalami KEK yang periksa di RSIA Citra Keluarga Kediri pada saat penelitian dilaksanakan.

Sampel dalam penelitian ini adalah sebagian ibu hamil yang mengalami KEK yang sedang melakukan pemeriksaan kehamilan di RSIA Citra Keluarga Kediri saat penelitian berlangsung.

Teknik pengambilan sampel yang digunakan dalam penelitian ini adalah Non Probability Sampling, yaitu Acidental Sampling, dengan mengambil sampel secara incidental pada ibu hamil dengan KEK yang sedang melakukan pemeriksaan kehamilan di RSIA Citra Keluarga pada saat dilakukam penelitian.

Kriteria dalam penelitian ini, adalah :

1. Ibu hamil dengan KEK yang sedang melakukan pemeriksaan kehamilan di RSIA Citra Keluarga Kediri.

2. Ibu hamil dengan KEK yang bersedia menjadi responden dan dilakukan pengukuran berat badan dan tinggi badan.

3. Ibu hamil yang bisa membaca dan menulis.

Analisa univariat yang dilakukan pada tiap variabel dari hasil penelitian yang bertujuan untuk menjelaskan atau mendiskripsikan karakteristik setiap variabel penelitian.

Analisis Bivariat dengan menggunakan uji statistik yang dipilih berdasarkan tujuan uji yaitu hubungan (korelasi / asosiasi), dikarenakandata yang didapatkan ordinal maka menggunakan uji Spearman Rank. Untuk keperluan analisis ini teknik ujinya dengan menggunakan bantuan komputer.

Analisis multivariat yang digunakan dalam penelitian ini adalah regresi logistik ganda karena variabel dependennya satu yaitu kejadian KEK pada ibu hamil, dan data berbentuk kategorik, sedangkan variabel independennya lebih dari dua yaitu faktor pendidikan, usia, paritas, dan jarak kehamilan, sedangkan datanya berbentuk kategorik. Interpretasi analisis multivariat regresi logistik ganda adalah $p$-value < 0,25 maka variabel tersebut mempunyai pengaruh yang bermakna terhadap variabel lain. Jika $p$-value $>0,25$ maka varibel tersebut tidak mempengaruhi variabel yang lain.

\section{HASIL PENELITIAN}

\section{Analisa Univariat}

a. Data Karakteristik Responden Berdasarkan Pendidikan

Tabel 1 Distribusi Frekuensi Responden Berdasarkan Pendidikan di RSIA Citra KeluargaTahun 2015

\begin{tabular}{clcc}
\hline No. & Pendidikan & Frekuensi & $\begin{array}{c}\text { Prosentase } \\
(\mathbf{\%})\end{array}$ \\
\hline 1. & $\begin{array}{l}\text { Pendidikan } \\
\text { Dasar (SD, }\end{array}$ & 8 & 24,25 \\
2MP) & $\begin{array}{l}\text { SMP) } \\
\text { Pendidikan } \\
\text { Menengah } \\
\text { (SMA) }\end{array}$ & 18 & 54,55 \\
3. & $\begin{array}{l}\text { Pendidikan } \\
\text { Tinggi }\end{array}$ & 7 & 21,20 \\
\hline & Jumlah & 33 & 100 \\
\hline
\end{tabular}

Sumber : Data Primer Hasil Penelitian Tahun 2015

Tabel 1 menunjukkan bahwa sebagian besar responden, yaitu sebanyak 18 orang $(54,55 \%)$ berpendidikan SMA. Ada sebagian kecil $(24,25 \%)$ dari responden yang berpendidikan dasar, dimana hal ini 
merupakan permasalahan yang harus diperhatikan. Wajib belajar 9 tahun, semestinya bukan merupakan batasan untuk mencapai tingkat pendidikan karena masih ada jenjang pendidikan yang lebih tinggi yang harus ditempuh.

\section{b. Data Karakteristik Responden}

Berdasarkan Usia

Tabel 2 Distribusi Frekuensi Responden

Berdasarkan Usia di RSIA Citra Keluarga Kediri

\begin{tabular}{clcc}
\hline No. & Usia & Frekuensi & $\begin{array}{c}\text { Prosentase } \\
(\%)\end{array}$ \\
\hline 1. & $\begin{array}{l}\text { Berisiko } \\
(<20 \text { th }\end{array}$ & 12 & 36,36 \\
& $\begin{array}{l}\text { atau } \\
>35 \text { th })\end{array}$ & 21 & 63,64 \\
2. & $\begin{array}{l}\text { Tidak } \\
\text { berisiko } \\
(20-35\end{array}$ \\
& & \\
\hline & Jahun $)$ & 33 & 100 \\
\hline
\end{tabular}

Sumber : Data Primer Hasil Penelitian Tahun 2015

Tabel 2 menunjukkan bahwa sebagian besar responden $(63,64 \%)$ berada pada usia yang tidak berisiko, yaitu berada di usia 20-35 tahun. Hampir setengah $(36,36 \%)$ dari ibu hamil di RSIA Citra Keluarga Kediri, berusia $<20$ tahun dan $>35$ tahun. Kehamilan diusia yang berisiko ini berbanding lurus dengan tingkat pendidikan yang rendah, hal ini dikarenakan setelah berhenti sekolah maka tidak lagi ada kewajiban untuk belajar, sehingga terjadilah pernikahan diusia dini.

\section{c. Data Karakteristik Responden}

BerdasarkanParitas

Tabel 3 Distribusi Frekuensi Responden Berdasarkan Paritas di RSIA Citra KeluargaTahun 2015

\begin{tabular}{clcc}
\hline No & \multicolumn{1}{c}{ Paritas } & Frekuensi & $\begin{array}{c}\text { Prosentase } \\
(\mathbf{\%})\end{array}$ \\
\hline 1. & $\begin{array}{l}\text { Berisiko } \\
\text { (Grandemulti para) }\end{array}$ & 2 & 6,10 \\
2. & $\begin{array}{l}\text { Tidak Berisiko } \\
\text { (Primi dan Multi } \\
\text { para) }\end{array}$ & 31 & 93,90 \\
\hline & Jumlah & 33 & 100 \\
\hline
\end{tabular}

Sumber : Data Primer Hasil Penelitian Tahun 2015
Tabel 3 menunjukkan bahwa hampir seluruh responden $(93,90 \%)$ berada pada kehamilan yang tidak berisiko (Primi dan Multi para). Jumlah Ibu hamil dengan grande multi hanya 2 orang $(6,10 \%)$, namun hal ini perlu mendapatkan perhatian karena ibu dengan grande multi para berisiko mengalami gangguan pada kehamilan, persalinan dan nifas, juga risiko pada janin yang dikandungnya.

d. Data Karakteristik Responden Berdasarkan Jarak Kehamilan

Tabel 4 Distribusi Frekuensi Responden Berdasarkan Jarak Kehamilan di RSIA Citra KeluargaTahun 2015

\begin{tabular}{clcc}
\hline No. & $\begin{array}{l}\text { Jarak } \\
\text { Kehamilan }\end{array}$ & Frekuensi & $\begin{array}{c}\text { Prosentase } \\
(\mathbf{\%})\end{array}$ \\
\hline 1. & $\begin{array}{l}\text { Berisiko } \\
(<2 \text { th atau }\end{array}$ & 7 & 21,21 \\
& $\begin{array}{l}>4 \text { th) } \\
\text { Tidak } \\
\text { Berisiko } \\
(2-4 \text { tahun })\end{array}$ & 26 & 78,79 \\
\hline & Jumlah & 33 & 100
\end{tabular}

Sumber : Data Primer Penelitian Tahun 2015

Tabel 4 menunjukkan bahwa hampir seluruh responden (78,79\%), yaitu sebanyak 26 orang Ibu Hamil memiliki jarak kehamilan yang tidak berisiko (2-4 tahun). Jarak kehamilan berisiko masih ditemukan pada sebagian kecil $(21,21 \%)$ ibu hamil. Seorang ibu harus bisa mengatur jarak kehamilannya, karena jarak kehamilan yang terlalu dekat, membuat ibu tidak punya cukup waktu untuk istirahat dan mempersiapkan tubuhnya dalam menghadapi kehamilan yang berikutnya.

e. Data Karakteristik Responden

Berdasarkan Kejadian KEK

Tabel 5 Distribusi Frekuensi Responden Berdasarkan Pendidikan di RSIA Citra KeluargaTahun 2015

\begin{tabular}{cccc}
\hline No. & $\begin{array}{l}\text { Kejadian } \\
\text { KEK }\end{array}$ & Frekuensi & $\begin{array}{c}\text { Prosentase } \\
(\%)\end{array}$ \\
\hline 1. & KEK & 11 & 33,33 \\
& $\begin{array}{l}\text { Berat } \\
\text { KEK }\end{array}$ & 22 & 66,67 \\
& $\begin{array}{l}\text { Ringan } \\
\text { Jumlah }\end{array}$ & 33 & 100 \\
\hline \multicolumn{3}{l}{ Sumber : Data Primer Penelitian Tahun 2015 }
\end{tabular}


Tabel 5 menunjukkan bahwa sebagian besar responden, yaitu 22 orang $(66,67 \%)$ mengalami KEK ringan. Hampir setengah responden $(33,33 \%)$ mengalami KEK Berat. Hal ini merupakan permasalahan yang harus ditangani secara serius, karena seseorang bisa sampai jatuh dalam kondisi KEK memerlukan waktu yang tidak sebentar.

\section{Analisa Bivariat}

Analisa Bivariat dilakukan untuk melihat hubungan antara variabel dependen dengan variabel independen. Dalam penelitian ini menggunakan uji Spearrman Rank.

a. Distribusi Frekuensi Pengaruh Pendidikan terhadap Kejadian KEK pada Ibu Hamil di RSIA Citra Keluarga Kediri

Tabel 6 Distribusi Frekuensi Hubungan Pendidikan dengan Kejadian KEK pada Ibu Hamildi RSIA Citra Keluarga Tahun 2015

\begin{tabular}{|c|c|c|c|c|c|}
\hline \multirow{3}{*}{ No } & \multirow{3}{*}{$\begin{array}{c}\text { Pendidik } \\
\text { an }\end{array}$} & \multicolumn{2}{|c|}{ Kejadian KEK } & \multirow[t]{2}{*}{ Total } & \multirow[t]{2}{*}{$p$-value } \\
\hline & & $\begin{array}{l}\text { KEK } \\
\text { Berat }\end{array}$ & $\begin{array}{c}\text { KEK } \\
\text { Ringan }\end{array}$ & & \\
\hline & & $\mathrm{N}$ & $\mathrm{N}$ & $\mathrm{N}$ & \\
\hline 1. & Dasar & 6 & 2 & 8 & 0,009 \\
\hline 2. & $\begin{array}{l}\text { Meneng } \\
\text { ah }\end{array}$ & 5 & 13 & 18 & \\
\hline 3. & Tinggi & 0 & 7 & 7 & \\
\hline & Total & 11 & 22 & 33 & \\
\hline
\end{tabular}

Sumber : Data Primer Penelitian Tahun 2015

Berdasarkan tabel 6 di atas diperoleh data bahwa dari 33 responden, 11 orang yang mengalami KEK Berat, adalah berpendidikan dasar yaitu sebanyak 6 responden $(18,15 \%)$, pendidikan menengah sebanyak 5 responden $(15,16 \%)$, dan berpendidikan tinggi 0 (tidak ada). Responden yang mengalami KEK Ringan, berjumlah 22 orang, yang memiliki pendidikan dasar sebanyak 2 responden $(6,10 \%)$, menengah sebanyak 13 responden $(39,39 \%)$, tinggi sebanyak 7 responden $(21,20 \%)$.

Responden dengan pendidikan dasar sejumlah 8 orang, dari 8 responden tersebut yang mengalami KEK berat 6 orang dan KEK ringan 2 orang. Pendidikan yang rendah berkontribusi untuk terjadinya KEK berat, karena dari 7 responden yang berpendidikan tinggi, tak satupun yang mengalami KEK berat.

Hasil analisa dengan menggunakan rumus Uji Spearrman diperoleh $p$-value $=$ 0,009. Jadi $p$-value 0,05 sehingga $\mathrm{H}_{0}$ ditolak dan $\mathrm{H}_{1}$ diterima yaitu ada pengaruh faktor pendidikan terhadap kejadian KEK pada Ibu Hamil di RSIA Citra Keluarga Kediri Tahun 2015.

b. Distribusi Frekuensi Hubungan Usia dengan Kejadian KEK pada Ibu Hamil di RSIA Citra Keluarga Kediri

Tabel 7 Distribusi Frekuensi Pengaruh Usia terhadap Kejadian KEK pada Ibu Hamil di RSIA Citra Keluarga Tahun 2015

\begin{tabular}{|c|c|c|c|c|c|}
\hline \multirow{3}{*}{ No } & \multirow[t]{3}{*}{ Usia } & \multicolumn{2}{|c|}{ Kejadian KEK } & \multirow[t]{2}{*}{ Total } & \multirow{3}{*}{$\begin{array}{c}p- \\
\text { value }\end{array}$} \\
\hline & & $\begin{array}{l}\text { KEK } \\
\text { Berat }\end{array}$ & $\begin{array}{c}\text { KEK } \\
\text { Ringan }\end{array}$ & & \\
\hline & & $\mathbf{N}$ & $\mathbf{N}$ & $\mathbf{N}$ & \\
\hline 1. & $\begin{array}{l}<20 />35 \\
\text { Tahun }\end{array}$ & 7 & 5 & 12 & 0,027 \\
\hline 2. & 20-35 Tahun & 4 & 17 & 21 & \\
\hline & Total & 11 & 22 & 33 & \\
\hline
\end{tabular}

Sumber : Data Primer Penelitian tahun 2015

Berdasarkan tabel 7 di atas diperoleh data bahwa dari 33 responden sebesar 11 orang yang mengalami KEK Berat, dengan usia responden yang berisiko yaitu < 20 dan >35 tahun sebanyak 7 responden $(21,21 \%)$, yang berada pada usia antara 20-35 tahun sebanyak 4 responden $(12,12 \%)$. Ada 22 responden yang mengalami KEK Ringan dengan usia $<20$ dan $>35$ tahun sebanyak 5 responden $(15,15 \%)$, sedang yang berada pada rentang usia 20-35 tahun sebanyak 17 responden $(51,52 \%)$.

Responden dengan usia berisiko berjumlah 12 orang, yang mengalami KEK berat sebanyak 7 orang dan 5 orang mengalami KEK ringan. Jika dibandingkan dengan usia yang tidak berisiko, maka kejadian KEK berat lebih sering terjadi pada usia yang berisiko.

Hasil analisa dengan menggunakan rumus Uji Spearrman diperoleh $p$-value $=$ 
0,027. Jadi $p$-value $<0,05$ sehingga $\mathrm{H}_{0}$ ditolak dan $\mathrm{H}_{1}$ diterima yang berarti ada pengaruh faktor usia terhadap kejadian KEK pada Ibu Hamil di RSIA Citra Keluarga Kediri Tahun 2015.

c. Distribusi Frekuensi Pengaruh Paritas terhadap Kejadian KEK pada Ibu Hamil di RSIA Citra Keluarga Kediri

Tabel 8 Distribusi Frekuensi Hubungan Paritas dengan Kejadian KEK pada Ibu Hamil di RSIA Citra Keluarga Tahun 2015

\begin{tabular}{|c|c|c|c|c|c|}
\hline \multirow{3}{*}{ No } & \multirow[t]{3}{*}{ Usia } & \multicolumn{2}{|c|}{$\begin{array}{c}\text { Kejadian } \\
\text { KEK }\end{array}$} & \multirow[t]{2}{*}{ Total } & \multirow[t]{3}{*}{$\begin{array}{c}p- \\
\text { value }\end{array}$} \\
\hline & & $\begin{array}{l}\text { KEK } \\
\text { Berat }\end{array}$ & $\begin{array}{c}\text { KEK } \\
\text { Ring } \\
\text { an }\end{array}$ & & \\
\hline & & $\mathbf{N}$ & $\mathbf{N}$ & $\mathbf{N}$ & \\
\hline \multirow{3}{*}{$\begin{array}{l}1 . \\
2 .\end{array}$} & Berisiko & 2 & 0 & 2 & \multirow[t]{3}{*}{0,999} \\
\hline & $\begin{array}{l}\text { Tdk } \\
\text { Berisiko }\end{array}$ & 9 & 22 & 31 & \\
\hline & Total & 11 & 22 & 33 & \\
\hline
\end{tabular}

Sumber : Data Primer Penelitian tahun 2015

Berdasarkan tabel 8 di atas diperoleh data bahwa dari 33 responden, sebanyak 11 Ibu mengalami KEK Berat dengan Grande multi para sebanyak 2 responden $(6,10 \%)$, dan dengan primi maupun multi para sebanyak 9 responden $(27,23 \%)$. Respoden yang mengalami KEK Ringan dengan Grande multi para tidak ada, sedangkan dengan primi dan multi para sebanyak 22 responden $(66,67 \%)$.

Responden dengan grande multi para, semuanya mengalami KEK berat. Ibu dengan Grande multi para, terlalu sering melahirkan anak yaitu lebih dari 5 kali. Hal ini akan memberikan beban yang cukup berat kepada ibu karena untuk proses kehamilan membutuhkan asupan makanan yang lebih banyak baik untuk ibu maupun janinnya, begitu juga saat menyusui. Ibu harus memiliki waktu yang cukup untuk pemulihan tubuhnya, namun sebelum tubuhnya pulih, ibu harus hamil lagi dan membutuhkan energi yang lebih banyak lagi untuk kehamilan berikutnya, begitu seterusnya hingga lebih dari 5 kali.
Hasil analisa dengan menggunakan rumus Uji Spearrman diperoleh $p$-value $=$ 0,999. Jadi $p$-value $>0,05$ sehingga $\mathrm{H}_{0}$ diterima dan $\mathrm{H}_{1}$ ditolak yaitu tidak ada pengaruh faktor paritas terhadap kejadian KEK pada Ibu Hamil di RSIA Citra Keluarga Kediri Tahun 2015.

d. Distribusi Frekuensi Pengaruh Jarak Kehamilan terhadap Kejadian KEK pada Ibu Hamil di RSIA Citra Keluarga Kediri

Tabel 9 Distribusi Frekuensi Hubungan Jarak Kehamilan dengan Kejadian KEK pada Ibu Hamil di RSIA Citra Keluarga Tahun 2015

\begin{tabular}{llllll}
\hline \multirow{2}{*}{ No } & Usia & \multicolumn{2}{l}{ Kejadian KEK } & Total & p-value \\
\cline { 3 - 5 } & & $\begin{array}{c}\text { KEK } \\
\text { Berat }\end{array}$ & $\begin{array}{c}\text { KEK } \\
\text { Ringan }\end{array}$ & & \\
\cline { 3 - 5 } & & $\mathbf{N}$ & $\mathbf{N}$ & $\mathbf{N}$ & \\
\hline 1. & $\begin{array}{l}<2 />4 \\
\text { Tahun }\end{array}$ & 7 & 0 & 7 & 0,999 \\
2. & 2-4 Tahun & 4 & 22 & 26 & \\
\hline & Total & 11 & 22 & 33 & \\
\hline
\end{tabular}

Sumber : Data Primer Penelitian tahun 2015

Berdasarkan tabel 9 di atas diperoleh data bahwa dari 33 responden sebanyak 11 responden dengan KEK Berat yang memiliki jarak kehamilan $<2$ dan $>4$ tahun sebanyak 7 responden $(21,21 \%)$, dan dengan jarak kehamilan antara 2-4 tahun sebanyak 4 responden (12,12\%). Sedangkan Ibu Hamil dengan KEK Ringan sebesar 22 orang, tidak ada yang memiliki jarak kehamilan $<2$ atau $>4$ tahun, sedang Ibu Hamil dengan KEK Ringan yang memiliki jarak kehamilan antara 2-4 tahun sebanyak 22 responden $(66,67 \%)$.

Jarak kehamilan yang terlalu dekat, berkontribusi pada kejadian KEK berat, karena dari 7 responden yang memiliki jarak kehamilan terlalu dekat $(<2$ tahun), semuanya mengalami KEK berat dan tak satupun yang mengalami KEK ringan. Hal ini dikarenakan waktu pemulihan ibu paska bersalin masih belum cukup, bahkan ada ibu yang masih menyusui dan sedang mengandung adiknya. 
Hasil analisa dengan menggunakan rumus Uji Spearrman diperoleh $p$-value $=$ 0,999. Jadi $p$-value $>0,05$ sehingga $\mathrm{H}_{0}$ diterima dan $\mathrm{H}_{1}$ ditolak yang berarti tidak ada pengaruh faktor jarak kehamilan terhadap kejadian KEK pada Ibu Hamil di RSIA Citra Keluarga Kediri Tahun 2015.

\section{Analisa Multivariat}

Interpretasi analisis multivariat model regresi adalah dengan menyeleksi variabel yang layak masuk ke dalam model multivariat. Dari hasil seleksi, didapatkan variabel yang berhubungan bermakna dengan kejadian KEK pada Ibu Hamil adalah variabel Pendidikan dan Usia.

Hasil analisis di dapatkan nilai OR variabel Pendidikan adalah 12,000 yang artinya pendidikan ibu berpeluang12 kali sebagai penyebab KEK Berat. Nilai OR variabel usia adalah 5,595 yang artinya usia memiliki peluang 5,595 kali sebagai penyebab kejadian KEK Berat.

\section{PEMBAHASAN}

\section{Pendidikan Ibu Hamil yang Mengalami KEK}

Sebagian besar responden, yaitu sebanyak 18 orang $(54,55 \%)$ berpendidikan SMA. Pendidikan adalah suatu proses bimbingan yang diberikan seseorang kepada orang lain dengan tujuan tertentu. Pendidikan dibagi menjadi dua yaitu pendidikan formal dan non formal. Masyarakat dengan pendidikan yang tinggi akan lebih mudah menerima ilmu maupun informasi baru, mereka akan lebih mudah beradaptasi dan mencari hal yang baru (Notoatmojdo, 2003).

Menurut pendapat peneliti, tingkat pendidikan yang ditempuh oleh seseorang dapat menentukan perilaku seseorang, misalnya perilaku dalam mengkonsumsi makanan. Makanan sebagai sumber energi, pengatur maupun pembangun dalam tubuh manusia. Jika seseorang kekurangan asupan makanan, maka akan berisiko mengalami kekurangan energi, protein dan zat makanan yang lain. Jika kekurangan asupan makanan berkepanjangan, maka tidak menutup kemungkinan seseorang akan mengalami KEK.

Meskipun tingkat pendidikan bukan faktor utama dalam kejadian KEK pada Ibu Hamil, namun diharapkan dengan semakin tingginya pendidikan seseorang, maka akan semakin mudah seseorang untuk menerima informasi. Harapannya dengan semakin tinggi pendidikan seseorang, maka akan semakin banyak pula pengetahuan dan informasi yang dimiliki, termasuk pemahaman tentang pemenuhan kebutuhan gizi seimbang untuk Ibu Hamil.

\section{Usia Ibu Hamil yang Mengalami KEK}

Sebagian besar responden $(63,64 \%)$ berada pada usia yang tidak berisiko, yaitu berada di usia 20-35 tahun. Usia yang semakin bertambah akan menyebabkan terjadi perubahan pada aspek fisik dan aspek psikologis. Semakin bertambahnya usia seseorang, maka akan semakin matang dan mampu berpikir tentang pentingnya untuk mengkonsumsi makanan dengan gizi seimbang untuk pertumbuhan dan perkembangan janin yang optimal di dalam kandungan (Notoatmodjo, 2003).

Semakin cukup umur maka tingkat kematangan dan kekuatan seseorang akan lebih baik dalam berfikir dan bekerja. Dalam kurun waktu reproduksi sehat dikenal bahwa usia aman untuk kehamilan, persalinan dan menyusui adalah 20-35 tahun. Oleh sebab itu, yang sesuai dengan masa reproduksi sangat baik dan sangat mendukung dalam pemenuhan gizi seimbang, sedangkan umur yang kurang dari 20 tahun dianggap masih belum matang secara fisik, mental dan psikologisnya dalam menghadapi kehamilan dan persalinan. Jika umur lebih dari 35 tahun dianggap juga berbahaya, sebab baik alat reproduksi maupun fisik ibu sudah mengalami penurunan. 
Menurut pendapat peneliti, semakin bertambah umur seseorang akan lebih mudah dalam menerima informasi yang diberikan oleh tenaga kesehatan tentang pentingnya mengkonsumsi makanan seimbang guna mencegah terjadinya KEK. Meskipun umur bukan faktor utama dalam kejadian KEK, namun diharapkan dengan semakin bertambahnya umur seseorang, maka akan lebih siapmenerima kehamilannya, baik dari segi fisik maupun psikologisnya, sehingga Ibu Hamil akan memperhatikan danmemikirkan kesejahteraan janin yang dikandungnya.

\section{Paritas Ibu Hamil yang Mengalami KEK}

Hampir seluruh responden $(93,90 \%)$ berada pada kehamilan yang tidak berisiko (Primi dan Multi Para). Hanya sebagian kecil $(6,10 \%)$ saja responden yang mengalami kehamilan yang berisiko (Grande Multi Para). Dari hasil penelitian tersebut, menunjukkan bahwa kesadaran masyarakat untuk merencanakan jumlah anak mulai tinggi. Masyarakat menyadari risiko dan bahaya yang akan terjadi jika memiliki anak lebih dari 5 (lima) orang atau biasa disebut dengan Grande multi para. Kehamilan sering dapat menyebabkan gizi kurang karena dapat menguras cadangan zat gizi tubuh serta organ reproduksi belum kembali sempurna seperti sebelum masa kehamilan (Departemen Gizi dan Kesmas FKMUI, 2007).

Menurut pendapat peneliti, semakin banyak jumlah anak yang dimiliki dalam keluarga, maka akan semakin menambah beban keluarga tersebut. Program Keluarga Berencana (KB), telah sukses dalam menurunkan angka kelahiran. Jika ibu mau mengikuti program $\mathrm{KB}$, maka mereka bisa merencanakan jumlah anak yang akan dilahirkannya, bisa mengatur keuangan dalam keluarga dan lebih fokus dalam mengasuh dan mendidik anaknya. Meskipun paritas bukan faktor utama dalam kejadian KEK, namun diharapkan dengan kesadaran untuk merencanakan jumlah anak, maka seorang ibu akan lebih siap untuk menerima kehamilannya baik dari segi fisik maupun psikologis.

\section{Jarak Kehamilan pada Ibu Hamil yang mengalami KEK}

Hampir seluruh responden, yaitu sebanyak 26 orang $(78,79 \%)$ memiliki jarak kehamilan yang tidak berisiko. Ibu dikatakan terlalu sering melahirkan bila jaraknya kurang dari 2 tahun. Penelitian menunjukkan bahwa apabila keluarga dapat mengatur jarak diantara kelahiran anaknya lebih dari 2 tahun maka anak akan lebih sehat dibanding anak dengan jarak kelahiran dibawah 2 tahun (Aguswilopo, 2004).

Jarak melahirkan yang terlalu dekat akan menyebabkan kualitas janin/anak yang rendah dan juga akan merugikan kesehatan ibu. Ibu tidak memperoleh kesempatan untuk memperbaiki tubuhnya sendiri, karena ibu memerlukan energi yang cukup untuk memulihkan keadaan setelah melahirkan anaknya. Saat ibu mengandung kembali, maka akan menimbulkan masalah gizi pada ibu dan janin/bayi berikutnya yang sedang dikandung (Baliwati, 2004).

Menurut pendapat peneliti, jarak kehamilanyang terlalu dekat akan lebih banyak menimbulkan masalah pada ibu, karena ibu harus menyiapkan energi yang cukup untuk menyiapkan kondisi fisiknya paska persalinan. Untuk itu, ibu hamil cenderung mengatur jarak kehamilannya dengan berbagai upaya, termasuk mengikuti program KB. Jika jarak kehamilan terlalu dekat, maka ibu hamil akan berisiko mengalami kekurangan energi, protein dan zat makanan yang lain.

Meskipun jarak kehamilan bukan faktor utama dalam kejadian KEK pada Ibu Hamil, namun diharapkan dengan pengaturan jarak kehamilan, maka faktor risiko sebagai akibat hal tersebut dapat dihindarkan, baik risiko pada ibu maupun janin/bayi yang dilahirkan. 


\section{Kejadian KEK pada Ibu Hamil}

Sebagian besar responden $(66,67 \%)$ mengalami KEK Ringan. KEK adalah suatu keadaan kekurangan makanan dalam waktu yang lama sehingga menyebabkan ukuran indeks massa tubuhnya atau IMT dibawah normal $(<18,5)$ untuk orang Indonesia (Sandjaja, 2009). Jika keadaan ini dibiarkan dapat berdampak pada ibu berupa anemia, perdarahan, berat badan ibu tidak bertambah secara normal dan mudah terkena penyakit infeksi (Adriani, 2012). Efek dari perubahan jumlah makanan yang dikonsumsi dapat cukup berbeda menurut keseluruhan menu makanananya. Jadi, peningkatan berat badan lahir bayi bukan hanya dapat dicapai melalui asupan energi yang moderat tetapi juga melalui perbaikan kualitas makanannya (peningkatan kepadatan nutrien) (Gibney, 2009).

Menurut Suhardjo (2005), status gizi kurang dan penyakit infeksi terdapat interaksi bolak balik. Infeksi dapat menimbulkan kurang gizi dan kurang gizi dapat mempermudah terinfeksi dengan penyakit. Jika ibu hamil terkenan infeksi maka penurunan asupan gizi akibat kurangnya nafsu makan, menurunnya absorbsi dan kebiasaan mengurangi makan saat sakit. Peningkatan kehilangan cairan/zat gizi akibat penyakit diare, mual/muntah dan perdarahan yang terus menerus (Supariasa, 2010).

Menurut peneliti, kejadian KEK pada ibu hamil bukan hanya masalah keluarga tersebut, namun juga merupakan masalah negara. Hal ini dikarenakan angka kematian ibu (AKI) maupun angka kematian bayi (AKB) merupakan indikator kesehatan suatu negara. Walaupun dari hasil penelitian menunjukkan sebagian besar mengalami KEK ringan, namun tidak boleh dikesampingkan jumlah KEK berat yang mencapai 33,33\%. Untuk itu Ibu Hamil harus mengkonsumsi makanan dengan gizi seimbang, agar dapat memenuhi kebutuhan nutrisi untuk janin yang dikandungnya dan juga untuk dirinya sendiri.

\section{Hubungan Pendidikan dengan Kejadian KEK pada Ibu Hamil}

Berdasarkan hasil analisa dengan menggunakan rumus Uji Spearrman diperoleh $p$-value $=0,009$. Jadi $p$ value $<0,05$ sehingga $\mathrm{H}_{0}$ ditolak dan $\mathrm{H}_{1}$ diterima yaitu ada pengaruh faktor pendidikan terhadap kejadian KEK pada Ibu Hamil di RSIA Citra Keluarga Kediri Tahun 2015.

Tingkat pendidikan dasar umumnya kurang memahami kaitan konsumsi makanan jika dibandingkan dengan pendidikan menengah, apalagi dengan pendidikan tinggi. Hal ini sesuai dengan hasil penelitian, dimana responden dengan pendidikan tinggi, tidak satupun yang mengalami KEK Berat.

Pada pendidikan rendah, akses mengenai informasi pentingnya gizi untuk ibu hamil dan juga pemilihan bahan makanan yang bergizi dengan kualitas baik masih sangat kurang. Tingkat pendidikan yang rendah juga memungkinkan rendahnya pengetahuan ibu hamil tentang asupan gizi dan kesehatan karena kurang memanfaatkan pelayanan kesehatan yang tersedia (Yuliantini, 2004).

Menurut pendapat peneliti bahwa responden dengan pendidikan yang tinggi lebih cepat dan lebih mudah menerima informasi tentang pentingnya mengkonsumsi makanan dengan gizi seimbang pada Ibu Hamil. Kedepannya, diharapkan responden dengan pendidikan tinggi tidak ada lagi yang menderita KEK meskipun dalam grade yang ringan sekalipun, dan responden dengan pendidikan dasar juga mampu meningkatkan status gizinya.

Pendidikan dan pengetahuan mempengaruhi berat ringannya KEK yang dialami ibu hamil. Jika ibu mengalami KEK saat sebelum kehamilan dan memiliki pendidikan yang rendah, maka akan semakin memperberat KEK yang 
dialami. Hal itu dikarenakan kurangnya pengetahuan dan penangkapan informasi, sehingga penyajian makanan dalam keluarga dan kualitas makanan keluarga kurang memenuhi standar gizi seimbang. Status gizi ibu hamil, juga dapat dipengaruhi oleh pola makan ibu. Untuk itu, dalam memilih makanan harus memperhatikan kualitas makanan dan tidak hanya memperhatikan kuantitas makanan. Hal ini sesuai dengan penelitian Marice Simarmata (2008), yaitu terdapat hubungan antara pola konsumsi makanan dengan kejadian KEK hal itu terjadi karena kurangnya variasi makanan dan kurangnya rata-rata kecukupan gizi (energi dan protein) yang masih dibawah angka kecukupan gizi yang dianjurkan, sehingga faktor pola makanan dapat mempengaruhi kejadian KEK.

\section{Hubungan Usia dengan Kejadian KEK pada Ibu Hamil}

Hasil analisa dengan menggunakan rumus Uji Spearrman diperoleh $p$-value $=$ 0,027. Jadi $p$-value $<0,05$ sehingga $\mathrm{H}_{0}$ ditolak dan $\mathrm{H}_{1}$ diterima yang berarti ada pengaruh faktor usia terhadap kejadian KEK pada Ibu Hamil di RSIA Citra Keluarga Kediri Tahun 2015. Usia pada waktu hamil berpengaruh terhadap gizi ibu hamil. Semakin tua umur ibu hamil, energi yang dibutuhkan pada waktu hamil juga semakin tinggi (Wibisono, 2009). Penyebab KEK adalah akibat dari ketidak seimbangan asupan makanan untuk pemenuhan kebutuhan dan pengeluaran energi. Status gizi ibu hamil KEK adalah kehamilan pada ibu berusia muda (kurang dari 20 tahun), kehamilan yang terlalu sering serta kehamilan pada usia terlalu tua (> 35 tahun) (Achadi, 2007).

Adanya hubungan antara usia ibu hamil dengan kejadian KEK pada ibu hamil senada dengan penelitian Surasih (2005) dari hasil analisis diperoleh ibu hamil yang usianya berisiko terkena KEK, mempunyai risiko terkena KEK sebesar 3,298 kali dibandingkan dengan ibu hamil yang usianya tidak berisiko terkena KEK.
Ibu dengan usia $\leq 20$ tahun pada umumnya belum mampu memenuhi kebutuhan gizinya sendiri. Jika pada usia tersebut ibu dalam keadaan hamil, maka dikhawatirkan pasokan gizi terutama protein untuk janin juga berkurang. Menurut penelitian Hardinsyah (2000) menujukkan bahwa risiko melahirkan BBLR lebih banyak dialami oleh ibu yang pada saat hamil berusia kurang dari 20 tahun dibanding dengan kelompok umur lainnya.

Demikian pula dianjurkan untuk tidak hamil diatas usia 35 tahun, karena risiko terhadap bayi maupun ibu meningkat. Jika hamil di usia yang tua, maka energi yang dibutuhkanpun juga lebih tinggi karena fungsi organ yang makin melemah dan diharuskan bakerja maksimal maka memerlukan tambahan energi yang cukup guna mendukung kehamilan yang sedang berlangsung (Febry, 2013). Menurut penelitian Sri Mulyaningsih kehamilan pada usia lebih dari 35 tahun dengan kemunduran daya tahan tubuh dan berbagai penyakit maka dapat berisiko mengalami KEK. Ibu hamil dengan usia terlampau tua atau muda ditunjang dengan kondisi fisik yang kurang baik mengakibatkan kurangnya asupan makanan atau kurang nafsu makan, sehingga ibu mengalami anemia. Ibu hamil merupakan indikator yang rentan terkena anemia apalagi jika ibu tersebut memiliki status gizi yang tidak baik. Untuk itu ibu hamil harus memperoleh makanan bergizi, karena dengan asupan gizi yang baik, ibu hamil tidak akan mengalami anemia yang dapat mengakibatkan perdarahan, partus lama, syok, dan infeksi.

Risiko untuk semakin beratnya KEK akibat kehamilan di usia muda, dikarenakan tubuh masih belum mempersiapkan diri untuk menjalani proses kehamilan. Berdasarkan penelitian, responden yang memiliki usia berisiko untuk KEK dan mempunyai status KEK berat yaitu sebanyak $21,21 \%$, maka perbaikan gizi sebelum hamil sangat 
diperlukan. Pengukuran IMT dapat memantau kesesuaian berat badan calon ibu. Ibu dengan umur > 35 tahun juga mempengaruhi dalam asupan makanan karena dengan umur yang semakin tua, seringkali ibu kurang memperhatikan kehamilannya.

\section{Hubungan Paritas dengan Kejadian KEK pada Ibu Hamil}

Hasil analisa dengan menggunakan rumus Uji Spearrman diperoleh $p$-value $=$ 0,999. Jadi $p$-value $>0,05$ sehingga $\mathrm{H}_{0}$ diterima dan $\mathrm{H}_{1}$ ditolak yaitu tidak ada pengaruh faktor paritas terhadap kejadian KEK pada Ibu Hamil di RSIA Citra Keluarga Kediri Tahun 2015.

Penelitian Surasih (2005) menyatakan hal yang serupa bahwa tidak terdapat hubungan yang bermakna antara paritas dengan KEK, ibu hamil yang paritasnya lebih dari 3 kali mempunyai risiko relatif sama untuk terkena KEK dibandingkan dengan ibu hamil yang paritasnya kurang dari 3 kali. Paritas primipara dan multipara dapat berisiko menyebabkan KEK. Ibu hamil dengan paritas multipara sebenarnya juga berisiko sekali mengalami KEK karena kurang memperhatikan kehamilannya dengan jarang melakukan pemeriksaan ANC.

Menurut peneliti, Ibu dengan paritas $\leq 1$ dan usia muda berisiko mengakami KEK, karena ibu belum siap secara medis maupun secara mental, sedangkan paritas di atas 4 dan usia tua, secara fisik ibu mengalami kemunduran untuk menjalani kehamilan (Kemenkes RI, 2004). Tidak hanya ibu dengan paritas tinggi yang mengalami gangguan kesehatan dan menyebabkan angka kematian anak dan ibu tinggi, tetapi paritas rendah pun dapat juga mengalami gangguan kesehatan. Jika memiliki riwayat penyakit akan berisiko besar mengalami gangguan kesehatan dan penurunan asupan makanan. Selain adanya gangguan kesehatan, paritas multipara kurang memperhatikan kehamilannya dan merasa sudah berpengalaman dalam kehamilannya sehingga kurang memperhatikan informasi yang diberikan oleh tenaga kesehatan. Kurangnya informasi mengenai gizi akan memberikan dampak ketidak tahuan ibu tentang pentingnya variasi makanan dan kandungan makanan yang diperlukan untuk masa kehamilan, sehingga walaupun ibu hamil masih merupakan multipara dan primipara tetap diperlukan adanya suatu penyuluhan yang teratur selama pemeriksaan kehamilan.

\section{Hubungan Jarak Kehamilan dengan Kejadian KEK pada Ibu Hamil}

Hasil analisa dengan menggunakan rumus Uji Spearrman diperoleh $p$-value $=$ 0,999. Jadi $p$-value $>0,05$ sehingga $\mathrm{H}_{0}$ diterima dan $\mathrm{H}_{1}$ ditolak yang berarti tidak ada pengaruh faktor jarak kehamilan terhadap kejadian KEK pada Ibu Hamil di RSIA Citra Keluarga Kediri Tahun 2015.

Jarak melahirkan yang terlalu dekat akan menyebabkan kualitas janin/anak yang rendah dan juga akan merugikan kesehatan ibu. Ibu tidak memperoleh kesempatan untuk memperbaiki tubuhnya sendiri (ibu memerlukan energi yang cukup untuk memulihkan keadaan setelah melahirkan anaknya). Mengandung kembali maka akan menimbulkan masalah gizi ibu dan janin/bayi berikutnya yang sedang dikandung (Baliwati, 2004).

Dalam penelitian ini, jarak kehamilan tidak mempengaruhi kejadian KEK Berat, namun dari data yang diperoleh menunjukkan bahwa responden dengan jarak kehamilan $<2$ atau $>4$ tahun semuanya (7 responden) mengalami KEK Berat. Responden dengan jarak kehamilan antara 2-4 tahun, sebagian besar $(66,67 \%)$ mengalami KEK Ringan. Hal ini sesuai dengan teori, bahwa jarak kehamilan yang berisiko ( $<2$ atau $>4$ tahun) akan berisiko menimbulkan masalah gizi pada ibu maupun janin yang sedang dikandungnya.

Menurut pendapat peneliti, seorang ibu bersama suaminya harus bisa mengatur jarak kehamilannya, agar ibu dan janin tidak berisiko mengalami gangguan atau masalah gizi. Seorang ibu 
memerlukan waktu untuk pemulihan fisiknya setelah persalinan yang lalu, sehingga ibu perlu istirahat dan tidak langsung hamil untuk anak yang berikutnya.

\section{Analisis Faktor Determinan Kejadian KEK pada Ibu Hamil}

Hasil analisis di dapatkan nilai OR variable Pendidikan adalah 12,000 yang artinya pendidikan ibu berpeluang $12 \mathrm{kali}$ sebagai penyebab KEK Berat. Nilai OR variabel usia adalah 5,595 yang artinya usia memiliki peluang 5,595 kali sebagai penyebab kejadian KEK Berat. Sementara untuk variabel paritas dan variabel jarak kehamilan tidak terpilih menjadi model, dikarenakan nilai signifikannya $<\alpha$. Kejadian KEK Berat pada ibu hamil dipengaruhi oleh faktor pendidikan dan usia ibu, dan dapat disimpulkan bahwa pendidikan merupakan faktor dominan yang dapat mengakibatkan terjadinya KEK pada Ibu Hamil.

Pada dasarnya kejadian KEK pada Ibu Hamil, adalah suatu kondisi yang kronis dan memerlukan waktu yang cukup panjang sampai ditemukannya tanda dan gejala KEK. Keempat faktor determinan (pendidikan, usia, paritas, jarak kehamilan) tersebut saling mempengaruhi dan dalam jangka waktu yang cukup lama, bahkan kemungkinan sejak ibu belum merencanakan kehamilan.

Menurut peneliti, peningkatan tingkat pendidikan sangat diperlukan agar kualitas hidup seseorang bisa meningkat pula. Pendidikan dasar yang diwajibkan bagi seluruh warga negara saja tidaklah cukup. Guna meningkatkan pengetahuan seseorang, jika pendidikan formal tidak memadai maka pengetahuan bisa diperoleh dari pendidikan non formal. Selain itu, penundaan perkawinan dapat dilakukan dengan pencanangan wajib belajar yang bukan hanya 9 tahun tetapi 12 tahun. Harapan ke depannya, minimal tingkat pendidikan warga negara mencapai SMA dan tidak ada lagi kehamilan di usia kurang dari 20 tahun.

\section{KESIMPULAN}

1. Ibu yang mengalami KEK dan periksa di RSIA Citra Keluarga Kediri Tahun 2015, sebagian besar berpendidikan SMA

2. Ibu yang mengalami KEK dan periksa di RSIA Citra Keluarga Kediri Tahun 2015, sebagian besar berusia antara 2035 tahun.

3. Ibu yang mengalami KEK dan periksa di RSIA Citra Keluarga Kediri Tahun 2015, hampir seluruhnya berada pada kehamilan yang tidak berisiko (Primi dan Multi para).

4. Ibu yang mengalami KEK dan periksa di RSIA Citra Keluarga Kediri Tahun 2015, hampir seluruhnya memiliki jarak kehamilan yang tidak berisiko (24 tahun).

5. Sebagian besar Ibu yang periksa di RSIA Citra Keluarga Kediri Tahun 2015, mengalami KEK Ringan.

6. Ada pengaruh pendidikan terhadap kejadian KEK pada Ibu Hamil di RSIA Citra Keluarga Kediri Tahun 2015.

7. Ada pengaruh usia terhadap kejadian KEK pada Ibu Hamil di RSIA Citra Keluarga Kediri Tahun 2015.

8. Tidak ada pengaruh paritas terhadap kejadian KEK pada Ibu Hamil di RSIA Citra Keluarga Kediri Tahun 2015.

9. Tidak ada pengaruh jarak kehamilan terhadap kejadian KEK pada Ibu Hamil di RSIA Citra Keluarga Kediri Tahun 2015.

10. Melalui model Regresi di dapatkan hasil bahwa faktor yang berpengaruh terhadap kejadian KEK adalah pendidikan dan usia. Faktor yang memiliki pengaruh sangat kuat adalah pendidikan.

\section{SARAN}

\section{Bagi Tempat Penelitian}

Sebagai masukan untuk tempat penelitian, yaitu agar memberikan informasi tentang pentingnya makanan bergizi seimbang untuk ibu hamil dan 
cara penyajian serta pengolahan makanan yang benar.

2. Bagi Responden

Dengan penelitian ini diharapkan responden lebih mengerti dan memahami manfaat mengkonsumsi makanan dengan gizi seimbang, agar tidak terjadi KEK yang berulang.

3. Bagi Institusi Pendidikan

Penelitian ini diharapkan dapat bermanfaat bagi pengembangan ilmu kebidanan, khususnya dalam pencegahan KEK pada Ibu Hamil.

4. Peneliti Selanjutnya

Dari hasil penelitian ini diharapkan dapat digunakan sebagai acuan untuk melakukan penelitian dengan lebih mendetail dengan menganalisis faktor lainnya dan lebih sempurna lagi.

\section{DAFTAR PUSTAKA}

Achadi, E.L. (2007) Gizi Ibu dan Kesehatn Reproduksi. Dalam : Dep. Gizi dan kesehatan masyarakat, FKM UI " Gizi dan Kesehatan Masyarakat”. Jakarta: PT. Raja Grafindo Persada.

Adriani, M., Wirjatmadi, B. (2012) Peranan Gizi Dalam Siklus Kehidupan. Jakarta: Kencana Prenada Media Group.

Arikunto, S. (2006) Prosedur Penelitian Suatu Pendekatan Praktek. Jakarta : Rineka Cipta.

Arisman (2004) Gizi Dalam Daur Kehidupan : Buku Ajar Ilmu Gizi.Jakarta : EGC

Departemen Gizi dan Kesehatan Masyarakat FKM UI (2007) Gizi dan Kesehatan Masyarakat. Jakarta : PT. Raja Grafindo PersadaDinas Kesehatan Kabupaten Kediri (2013) Laporan Bagian Kesehatan Keluarga (KIA). Kediri: Dinkes Kabupaten Kediri.Departemen Pendidikan Nasional (2008) Kamus Besar Bahasa Indonesia Pusat Bahasa Edisi Keempat. Jakarta : PT.Gramedia Pustaka Utama.
Gibney, M.J. (2009) Gizi Kesehatan Masyarakat, alih bahasa: Andry Hartono. Jakarta : EGC.

Harahap, H. (2002) Faktor-Faktor yang Mempengaruhi Risiko Kekurangan Energi Kronik pada Wanita Usia Subur. Jakarta: Badan Litbangkes.

Haws, P.S. (2008) Asuhan Neonatus Rujukan Cepat.Jakarta, alih bahasa: H.Y Kuncara. Jakarta : EGC

Hidayat, A.A.A. (2007) Metode Kebidanan dan Tekhnik Analisis Data. Jakarta : Salemba.

Irpisar (2012) Ibu Hamil, Ayo Melek Gizi <http://health.okezone.com/index> diakses tanggal 20 Februari 2013 Jam 20.00 WIB.

Khomsan, A. (2003) Pangan dan Gizi Untuk Kesehatan. Jakarta : PT Raja Grafindo Persada.

Notoatmojo, S. (2003) Ilmu Kesehatan Masyarakat Prinsip-Prinsip Dasar. Jakarta: Rineka Cipta. (2010). Metodelogi Penelitian Kesehatan.Jakarta: Rineka Cipta

Paath, E.F. (2005) Gizi Dalam Kesehatan Reproduksi. Jakarta : EGC.

Pickett, G. (2009) Kesehatan Masyarakat : Administrasi dan Praktik, Ed. 9, alih bahasa: John J. Hanlon. Jakarta : EGC

Proverawati, A. (2010) Buku Ajar Gizi Untuk Kebidanan. Jogyakarta: Muha Medika

Riyanto, A. (2011) Aplikasi Metodologi Penelitian Kesehatan. Yogyakarta : Nuha Medika.

Rochjati, P. (2003) Skrining Antenatal pada Ibu Hamil. Surabaya : FK UNAIR.

Sandjaja, A. (2009) Kamus Gizi. Jakarta : PT. Kompas Media Nusantara. (2009) Risiko Kurang Energi Kronis (KEK) Pada Ibu Hamil Di Indonesia. Gizi Indon 2009, 32 (2): 128-138.

Soekirman (2006) Gizi Seimbang untuk Ibu Hamil. Jakarta : PT. Gramedia. 
Sugiyono (2007) Statistika Untuk Penelitian. Bandung : CV Alfabeta.

Sulistyawati, A. (2009) Asuhan Kebidanan Pada Masa Hamil. Jakarta : Salemba Medika.

Supariasa, I. D. N. (2012) Penilaian Status Gizi. Jakarta : EGC.

Surasih, H (2005) Faktor-faktor yang berhubungan dengan keadaan Kurang Energi Kronis (KEK) pada ibu hamil di Kabupaten Banjarnegara. Karya Tulis Ilmiah.

Thorn, G. (2004) Kehamilan Sehat, alih bahasa: Gregoria Yeni W. Jakarta : Erlangga.

Timmreck, T. (2005) Epidemiologi Suatu Pengantar Edisi 2, alih bahasa: Manuya Fauziah. Jakarta : EGC. 